\title{
EDUFORTECH
}

http://ejournal.upi.edu/index.php/edufortech/index

\section{PENGGUNAAN EDMODO PADA MATA KULIAH MEDIA PEMBELAJARAN PENDIDIKAN TEKNOLOGI AGROINDUSTRI UNTUK MENINGKATKAN SELF-REGULATED LEARNING MAHASISWA}

\section{Edmodo Use In Learning Media Course Of Agroindustry Technology Education To Enhance Students Self-Regulated Learning}

Herlina, Sri Handayani, Dwi Lestari Rahayu

Program Studi Pendidikan Teknologi Agroindustri, Universitas Pendidikan Indonesia E-mail: herlina.pro1@gmail.com

\begin{abstract}
ABSTRAK
Sistem pembelajaran pada pendidikan tinggi yang memberikan keleluasaan kepada mahasiswa untuk mengatur proses belajarnya sendiri menuntut mahasiswa memiliki kemampuan untuk meregulasi diri (SelfRegulated Learning) yang dapat diajarkan atau dilatih selama proses pembelajaran, salah satunya menggunakan e-portofolio. Penelitian ini bertujuan untuk mengetahui proses penggunaan e-portofolio Edmodo pada mata kuliah Media Pembelajaran Pendidikan Teknologi Agroindustri dan untuk mengetahui apakah pembelajaran menggunakan e-portofolio Edmodo dapat meningkatkan Self-Regulated Learning pada mahasiswa. Penelitian menggunakan Quasi Eksperimen dengan metode Nonequivalent (Pre-test and Post-test) Control-Group Design. Teknik sampling yang digunakan adalah sampling jenuh sehingga semua populasi digunakan menjadi sampel dengan jumlah sampel 63 orang, dari seluruh sampel hanya 52 angket yang dapat digunakan untuk dianalisis. Instrumen yang digunakan untuk mengumpulkan data menggunakan angket yang diadaptasi dari Motivated Strategies for Learning Questionnaire (MSLQ). Data angket yang terkumpul dianalisis menggunakan uji statistik nonparametrik yaitu dengan uji Wilcoxon dan Uji Mann-Whitney. Hasil analisis data menunjukkan tidak terdapat perbedaan nilai Self-Regulated Learning sebelum pembelajaran dan sesudah pembelajaran menggunakan Edmodo. Nilai Self-Regulated Learning antara kelompok eksperimen (menggunakan Edmodo) dan kelompok kontrol (konvensional) tidak berbeda secara signifikan. Meskipun demikian kelompok eksperimen menunjukkan perubahan waktu pengumpulan tugas oleh mahasiswa menjadi lebih cepat.
\end{abstract}

Kata kunci: edmodo, self-regulated learning, media pembelajaran

\begin{abstract}
Learning system in higher education that provides flexibility to students to regulate their own learning process requires students to have the ability to self-regulate Learning that can be taught or trained during learning process, one of which uses e-portfolios. This study aims to determine the process of using Edmodo e-portfolio in Learning Media courses and to find out whether learning using Edmodo e-portfolio can improve Self-Regulated Learning for students. The study used Quasi Experiment with the Nonequivalent (Pre-test and Post-test) Control-Group Design method. The sampling technique used was saturated sampling so that all populations were used as samples with a sample of 63 people, out of a total of only 52 questionnaires that could be used for analysis. The instrument used to collect data uses a questionnaire adapted from the Motivated Strategies for Learning Questionnaire. Questionnaire data collected was analyzed using nonparametric statistical tests, namely the Wilcoxon test and the MannWhitney test. The results of data analysis showed there were no differences in the value of Self-Regulated Learning before learning and after learning using Edmodo. The value of Self-Regulated Learning between the experimental group (using Edmodo) and the control group (conventional) did not differ significantly. Nevertheless the experimental group showed changes in the time of assignment by students to be faster.
\end{abstract}

Keywords: red chili, palm fruit, edible coating 


\section{PENDAHULUAN}

Pada jenjang pendidikan tinggi, mahasiswa diberikan kebebasan terhadap proses belajarnya sendiri atau proses belajar tidak didominasi oleh dosen atau pengajarnya. Hal tersebut menyebabkan keberhasilan atau prestasi belajar sangat ditentukan oleh kemampuan mahasiswa dalam mengoptimalkan diri dan lingkungannya untuk belajar. Sementara itu, digitalisasi dalam bidang informasi memberikan kemudahan sekaligus gangguan (distraction) pada proses belajar. Menurut Sumarmo (2004), ketika individu menghadapi tugas atau kajian mandiri seperti proyek terbuka atau pemecahan masalah, individu dihadapkan pada sumber informasi yang melimpah. Sumber tersebut mungkin relevan atau tidak, tergantung dari kebutuhan dan tujuan individu.

Masalah lain yang dihadapi mahasiswa dalam mengerjakan tugas adalah sering mengalami kemalasan dan melakukan penundaan pekerjaan atau sering disebut prokrastinasi. Prokrastinasi dapat terjadi akibat kurangnya kemampuan meregulasi diri dalam belajar pada diri seseorang. Hasil penelitian Safa'ati, dkk (2017) menunjukkan prokrastinasi memiliki korelasi negatif dengan regulasi diri. Artinya, jika tingkat regulasi tinggi maka tingkat prokrastinasi rendah dan begitu pula sebaliknya.

Kemampuan regulasi diri dalam belajar sering disebut dengan istilah Self-Regulated Learning. Menurut Zimmerman (2002), Self-Regulated Learning adalah proses pengarahan diri sendiri dimana pembelajar mengubah kemampuan mental mereka menjadi keterampilan akademik. Pengaturan diri mengacu pada pikiran, perasaan, dan perilaku yang dihasilkan sendiri yang berorientasi untuk mencapai tujuan. Psikolog pembelajaran sosial melihat struktur proses Self-Regulation dalam tiga fase siklus. Pertama fase Forethought, menunjuk pada proses dan keyakinan yang terjadi sebelum upaya untuk belajar; kedua fase Performance mengacu pada proses yang terjadi selama implementasi perilaku dan ketiga fase Self-Reflection mengacu pada proses yang terjadi setelah setiap upaya pembelajaran (Zimmerman, 2002).

Self-Regulated Learning terutama dibutuhkan oleh mahasiswa karena banyak materi perkuliahan yang harus dicari dan membutuhkan pendalaman secara mandiri. Disamping itu, di perguruan tinggi juga banyak terdapat tugas berupa proyek mandiri atau kelompok sehingga mahasiswa perlu memiliki kemampuan dalam perencanaan dan pengaturan waktu pengerjaan tugas. Salah satu mata kuliah yang memiliki tugas proyek mandiri adalah mata kuliah Media Pembelajaran dan TIK Pendidikan Teknologi Agroindustri. Pada mata kuliah ini, setiap mahasiswa diberikan tugas membuat berbagai media pembelajaran dengan diberikan tenggat waktu penyelesaian. Dalam mengerjakan tugas mata kuliah Media Pembelajaran dan TIK Pendidikan Teknologi Agroindustri mahasiswa juga sering mengalami prokrastinasi. Tugas tidak dikerjakan secara bertahap dan cenderung dikerjakan mendekati tenggat waktu pengumpulan. Sementara itu, dosen tidak dapat memantau perkembangan mahasiswa secara berkala karena tidak memiliki akses berbagi berkas yang aktual dan efektif.

Berdasarkan paparan latar belakang tersebut, penelitian ini bermaksud untuk menggunakan Edmodo pada mata kuliah Media Pembelajaran untuk meningkatkan Self-Regulated Learning pada mahasiswa. Oleh karena itu, perlu dilakukan pengukuran tingkat Self-Regulated Learning pada mahasiswa yang pada penelitian ini menggunakan angket yang diadaptasi dari The Motivated Strategies for Learning Questionnaire (MSLQ). Pengumpulan data menggunakan angket dipilih karena mudah digunakan pada jumlah sampel yang banyak dan waktu yang diperlukan untuk mengumpulkan data cukup singkat.

\section{METODE}

Penelitian ini termasuk ke dalam kategori Quasi Experimental sehingga menggunakan kelompok yang terbentuk secara alami. Metode yang digunakan adalah Nonequivalent (Pre-test and Post-test) Control-Group Design. Pada metode ini kedua kelompok eksperimen dan kontrol melakukan pre-test dan post-test. Sedangkan kelompok yang mendapat perlakuan hanya kelompok eksperimen (Creswell, 2009). Desain tersaji pada tabel 1. 
Tabel 1. Desain Penelitian

\begin{tabular}{llll}
\hline Kelas & Pre-test & Perlakuan & Post-test \\
\hline Eksperimen & $\mathrm{O}_{1}$ & $\mathrm{X}$ & $\mathrm{O}_{2}$ \\
\hline Kontrol & $\mathrm{O}_{1}$ & - & $\mathrm{O}_{2}$ \\
\hline
\end{tabular}

Populasi pada penelitian ini adalah mahasiswa Program Studi Pendidikan Teknologi Agroindustri, Fakultas Pendidikan Teknik dan Kejuruan, Universitas Pendidikan Indonesia, semester empat pada tahun ajaran 2018-2019 yang mengambil mata kuliah Media Pembelajaran dan TIK Pendidikan Teknologi Agroindustri. Pengambilan sampel dilakukan dengan sampling jenuh. Sampling jenuh adalah teknik penentuan sampel dengan semua anggota populasi digunakan sebagai sampel.

Instrumen penelitian berbentuk angket yang diadaptasi dari MSLQ dari Pintrich, dkk. (1991). Mahasiswa mengisi angket dengan skala likert 6 poin dari 1 "sangat tidak benar tentang saya" hingga 6 "sangat benar tentang saya". Item-item dengan kata-kata negatif harus dibalik sebelum skor individu dapat dihitung. Jika suatu item menggunakan kata negatif, seseorang yang memilih 1 untuk suatu item menerima skor 6 dan seterusnya. Oleh karena itu, 1 menjadi 6, 2 menjadi 5, dan 3 menjadi 4. Item terbalik terdapat pada nomor 25, 26, 28, dan 33.

Hasil angket kemudian diuji menggunakan Uji Normalitas. Karena hasil Uji Normalitas menunjukkan data tidak normal maka uji hipotesis dialnjutkan dengan Uji Wilcoxon untuk membandingkan nilai angket awal dengan angket akhir dan Uji Mann-Whitney untuk membandingkan nilai anget akhir pada kelompok eksperimen dengan kelompok kontrol.

Tabel 2. Kisi-Kisi Angket untuk Menilai Self-Regulated Learning (diadaptasi dari Pintrich, dkk, 1991)

\begin{tabular}{|c|c|c|c|c|}
\hline Indikator & Dimensi & Sub-indikator & $\begin{array}{l}\text { Jumlah } \\
\text { Soal }\end{array}$ & $\begin{array}{l}\text { Nomor } \\
\text { Soal }\end{array}$ \\
\hline \multirow{5}{*}{ MOTIVASI } & \multirow{3}{*}{$\begin{array}{l}\text { Komponen } \\
\text { Nilai }\end{array}$} & $\begin{array}{l}\text { Orientasi Belajar kepada } \\
\text { Tujuan Intrinsik }\end{array}$ & 3 soal & $2,14,23$ \\
\hline & & $\begin{array}{l}\text { Orientasi Belajar kepada } \\
\text { Tujuan Ekstrinsik }\end{array}$ & 2 soal & 9,18 \\
\hline & & Penilaian Terhadap Tugas & 3 soal & $1,22,29$ \\
\hline & \multirow{2}{*}{$\begin{array}{l}\text { Komponen } \\
\text { Harapan }\end{array}$} & $\begin{array}{ll}\text { Keyakinan } & \text { Terhadap } \\
\text { Kontrol Belajar } & \\
\end{array}$ & 1 soal & 4 \\
\hline & & $\begin{array}{l}\text { Self-efficacy untuk } \\
\text { Pembelajaran dan Kinerja }\end{array}$ & 3 soal & $3,30,36$ \\
\hline \multirow{7}{*}{$\begin{array}{l}\text { STRATEGI } \\
\text { BELAJAR }\end{array}$} & \multirow{3}{*}{$\begin{array}{l}\text { Strategi } \\
\text { Kognitif dan } \\
\text { Metakognitif }\end{array}$} & Mengorganisir Informasi & 3 soal & $6,10,19$ \\
\hline & & Berpikir Kritis & 3 soal & $8,31,32$ \\
\hline & & $\begin{array}{l}\text { Strategi Metakognitif untuk } \\
\text { Meregulasi Diri }\end{array}$ & 6 soal & $\begin{array}{l}5,13,15 \\
24,26,34\end{array}$ \\
\hline & \multirow{4}{*}{$\begin{array}{l}\text { Strategi } \\
\text { Manajemen } \\
\text { Sumber Daya }\end{array}$} & $\begin{array}{l}\text { Manajemen Waktu dan } \\
\text { Lingkungan Belajar }\end{array}$ & 4 soal & $\begin{array}{l}16,20,33, \\
35\end{array}$ \\
\hline & & Regulasi Upaya & 3 soal & $7,25,28$ \\
\hline & & Peer Learning & 2 soal & 12,27 \\
\hline & & $\begin{array}{l}\text { Mencari Bantuan dalam } \\
\text { Belajar }\end{array}$ & 3 soal & $11,17,21$ \\
\hline
\end{tabular}




\section{HASIL DAN PEMBAHASAN}

\section{Keterlaksanaan Model pembelajaran Discovery Learning dengan Bantuan Mind Mapping}

Proses penggunaan Edmodo untuk Mata Kuliah Media Pembelajaran \& TIK Pendidikan Teknologi Agroindustri pada kelompok eksperimen diawali dengan membuat akun. Kemudian setiap mahasiswa pada kelompok eksperimen masuk ke dalam grup kelas pada Edmodo yang telah dosen buat. Setelah seluruh mahasiswa pada kelompok eksperimen masuk ke dalam grup kelas dosen mulai mengumumkan tugas sesuai urutan pengumpulan sampai tugas terakhir di dalam Edmodo. Pada kelompok kontrol jadwal pengumpulan tugas diumumkan di kelas secara lisan oleh dosen kemudian jika mahasiswa telah menyelesaikan tugas dan ingin mengumpulkannya dapat langsung diserahkan kepada dosen pengampu menggunakan flash disk.

Pada penelitian ini baik kelompok eksperimen maupun kelompok kontrol dosen arahkan untuk dapat mengumpulkan tugas lebih awal dari tenggat waktu yang disampaikan. Selain itu, dosen juga memberikan dorongan pada proses belajar dengan memberikan kesempatan kepada mahasiswa untuk mendapatkan nilai tambahan. Agar mendapatkan nilai tambahan, mahasiswa harus dapat menyelesaikan tugas pokok lebih awal kemudian membuat tugas tambahan berupa membuat media pembelajaran dengan jenis materi yang berbeda dari tugas pokok. Namun, baik kelompok eksperimen maupun kelompok kontrol tidak ada yang mengumpulkan atau membuat tugas untuk mendapatkan nilai tambahan. Jadwal pengumpulan tugas untuk kelompok eksperimen yaitu menggunakan Edmodo dapat dilihat pada Tabel 3.

Tabel 3. Jadwal Pengumpulan Tugas

\begin{tabular}{|c|c|c|c|}
\hline No & Nama Tugas & $\begin{array}{c}\text { Tanggal } \\
\text { Pengumuman }\end{array}$ & $\begin{array}{c}\text { Tanggal } \\
\text { Pengumpulan }\end{array}$ \\
\hline 1. & Pembuatan Media Prezi & 14 Maret 2019 & 15 Maret 2019 \\
\hline 2. & $\begin{array}{l}\text { Pembuatan Media } \quad \text { Video } \\
\text { menggunakan Powtoon }\end{array}$ & 20 Maret 2019 & 21 Maret 2019 \\
\hline 3. & Pembuatan Media Video Tutorial & 21 Maret 2019 & 27 Maret 2019 \\
\hline 4. & $\begin{array}{l}\text { Pembuatan Media } \text { Website } \\
\text { Menggunakan WIX }\end{array}$ & 21 Maret 2019 & 10 April 2019 \\
\hline 5. & $\begin{array}{l}\text { Pembuatan Media Aplikasi } \\
\text { Belajar menggunakan Appy Pie }\end{array}$ & 13 Mei 2019 & 25 Mei 2019 \\
\hline
\end{tabular}

Pada kelompok eksperimen setelah jadwal disusun dan diunggah ke Edmodo menggunakan fitur Assingment, muncul pemberitahuan dan sebuah kolom yang dapat dilihat dan diisi pada akun mahasiswa. Tugas akan secara otomatis masuk ke dalam pemberitahuan deadline tugas per minggu sesuai urutan waktu dari yang paling dekat waktu pengumpulannya pada masing-masing akun mahasiswa. Pemberitahuan tugas juga secara otomatis masuk ke dalam kalender mahasiswa pada fitur Edmodo Planner seperti pada Gambar 1.

Setelah tugas diumumkan di dalam Edmodo, mahasiswa pada kelompok eksperimen dapat langsung mengumpulkan tugas secara pada masing-masing akun sehingga tidak perlu menunggu saat bertemu dengan dosen pengampu mata kuliah. Tampilan tugas yang masuk ke dalam akun dosen terlihat seperti pada Gambar 2. Dosen dapat langsung memberikan nilai pada tugas yang dikumpulkan oleh mahasiswa dan nilai tersebut dapat langsung diterima oleh mahasiswa yang bersangkutan. Selain itu, jika mahasiswa melakukan kesalahan atau harus melakukan perbaikan pada tugasnya dosen dapat langsung menyampaikannya melalui kolom komentar. Kolom komentar juga dapat digunakan oleh dosen untuk memberikan masukan, penguatan pada perilaku positif, dan komunikasi lainnya. 


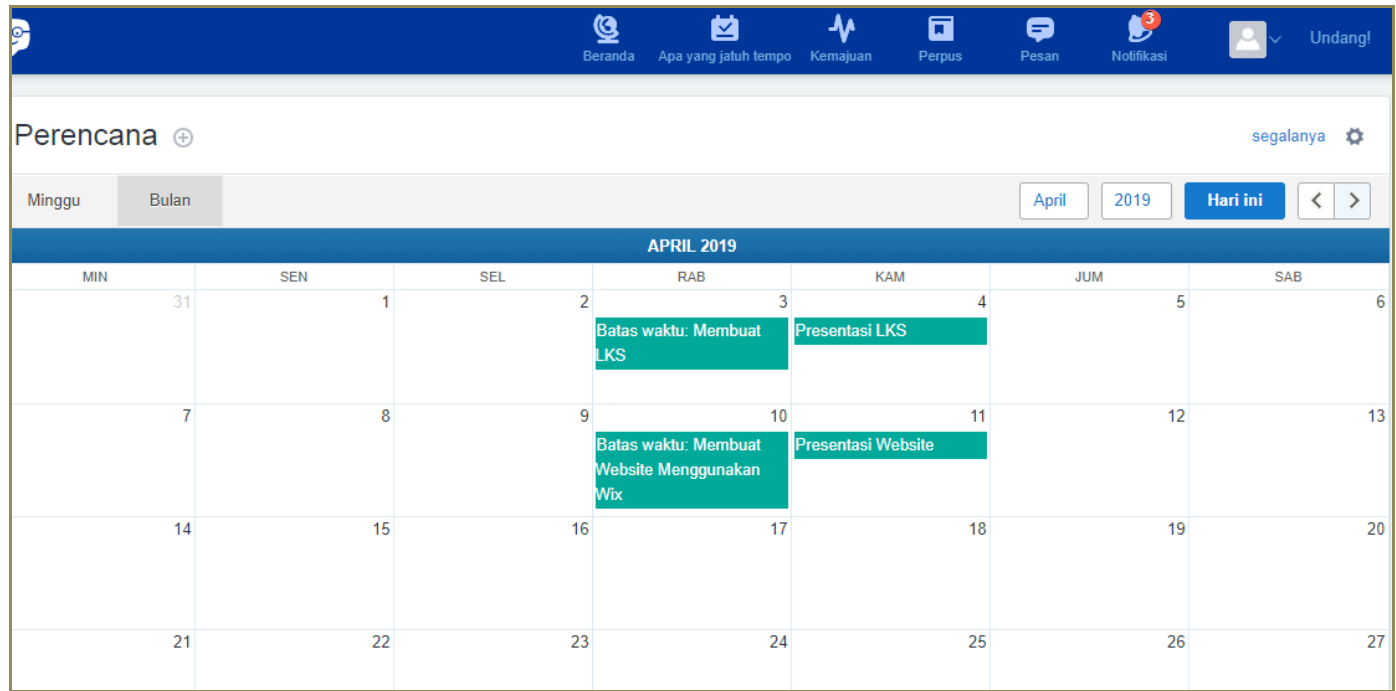

Gambar 1 Pemberitahuan Pengumpulan Tugas pada Fitur Edmodo Planner

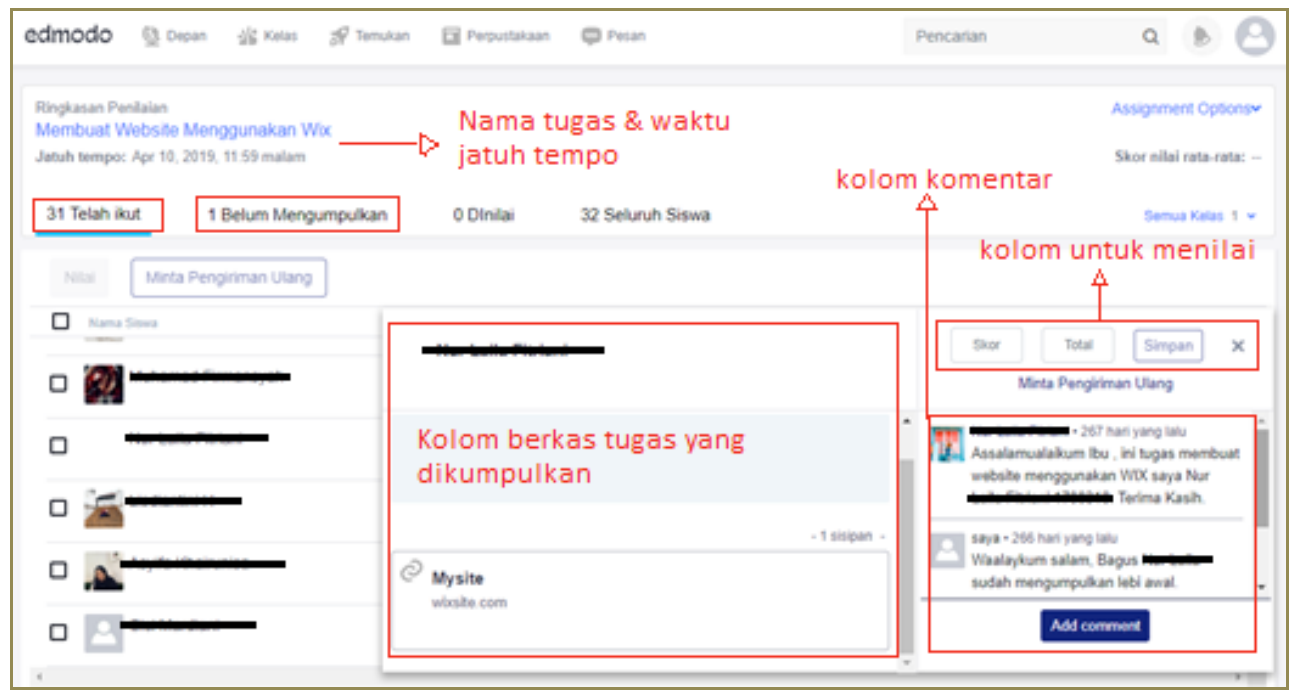

Gambar 2 Tampilan Pengumpulan Tugas Melalui Edmodo

Data pengumpulan tugas pada kelompok eksperimen secara terperinci terdapat pada Tabel 3 dan Tabel 4 memperlihatkan pengumpulan tugas pada kelompok kontrol. Terdapat beberapa mahasiswa kelompok eksperimen yang dapat menyelesaikan tugas sebelum tenggat waktu yang ditentukan namun terdapat juga mahasiswa yang terlambat mengumpulkan melalui Edmodo. Mahasiswa yang terlambat mengumpulkan melalui Edmodo mengumpulkan pada pertemuan di kelas melalui flash disk. Pada setiap pengumpulan tugas terdapat mahasiswa yang terlambat mengumpulkan melalui Edmodo mulai dari tugas pertama terdapat 5 mahasiswa kemudian pada tugas terakhir menurun menjadi 1 orang mahasiswa. Pada kelompok kontrol semua mahasiswa mengumpulkan tepat waktu saat pertemuan di kelas dan tidak ada yang mengumpulkan lebih awal karena tugas hanya dapat dikumpulkan pada hari presentasi di kelas. Mahasiswa yang terlambat pada kelompok kontrol adalah mahasiswa yang tidak hadir pada pertemuan di kelas. 
Tabel 3. Waktu Pengumpulan Tugas oleh Mahasiswa Kelompok Eksperimen

\begin{tabular}{|c|c|c|c|c|c|c|}
\hline \multirow[b]{2}{*}{ No } & \multirow[b]{2}{*}{ Nama Tugas } & \multicolumn{5}{|c|}{ Waktu Pengumpulan oleh Mahasiswa (Hari ke-) } \\
\hline & & $\begin{array}{c}\text { Tepat } \\
\text { waktu (a) }\end{array}$ & 1 s.d $3^{(b)}$ & 4 s.d $6^{(c)}$ & $\geq 7^{\text {(d) }}$ & Terlambat ${ }^{(\mathrm{e})}$ \\
\hline 1. & Pembuatan Media Prezi & $\begin{array}{c}27 \\
\text { orang }\end{array}$ & - & - & - & 5 orang \\
\hline 2. & $\begin{array}{l}\text { Pembuatan Media Video } \\
\text { menggunakan Powtoon }\end{array}$ & $\begin{array}{c}24 \\
\text { orang }\end{array}$ & 6 orang & - & - & 2 orang \\
\hline 3. & $\begin{array}{l}\text { Pembuatan Media Video } \\
\text { Tutorial }\end{array}$ & $\begin{array}{c}23 \\
\text { orang }\end{array}$ & 2 orang & 2 orang & - & 5 orang \\
\hline 4. & $\begin{array}{l}\text { Pembuatan Media Website } \\
\text { Menggunakan WIX }\end{array}$ & $\begin{array}{c}20 \\
\text { orang }\end{array}$ & 3 orang & 1 orang & $\begin{array}{c}6 \\
\text { orang } \\
\end{array}$ & 1 orang \\
\hline 5. & $\begin{array}{l}\text { Pembuatan Media Aplikasi } \\
\text { Belajar menggunakan Appy } \\
\text { Pie }\end{array}$ & 7 orang & 24 orang & - & - & 1 orang \\
\hline
\end{tabular}

Keterangan:

Tepat waktu: Jumlah mahasiswa yang mengumpulkan tepat pada tenggat waktu pada Edmodo.

$\mathrm{H}-1 \mathrm{~s}$.d 3 : Jumlah mahasiswa yang mengumpulkan $1 \mathrm{~s} . \mathrm{d} 3$ hari sebelum tenggat waktu pada Edmodo.

$\mathrm{H}-4$ s.d 6 : Jumlah mahasiswa yang mengumpulkan 4 s.d 6 hari sebelum tenggat waktu pada Edmodo.

$\mathrm{H}-\geq 7$ : Jumlah mahasiswa yang mengumpulkan 7 hari atau lebih sebelum tenggat waktu pada Edmodo.

Terlambat: Jumlah mahasiswa yang terlambat mengumpulkan melalui Edmodo dan mengumpulkan saat hari presentasi.

Tabel 4. Waktu Pengumpulan Tugas oleh Mahasiswa Kelompok Kontrol

\begin{tabular}{|c|c|c|c|}
\hline \multirow{2}{*}{ No } & \multirow{2}{*}{ Nama Tugas } & \multicolumn{2}{|c|}{ Waktu Pengumpulan oleh Mahasiswa } \\
\hline & & Tepat Waktu ${ }^{\text {(a) }}$ & Terlambat ${ }^{(b)}$ \\
\hline 1. & Pembuatan Media Prezi & 28 orang & 3 orang \\
\hline 2. & Pembuatan Media Video menggunakan Powtoon & 27 orang & 4 orang \\
\hline 3. & Pembuatan Media Video Tutorial & 31 orang & - \\
\hline 4. & Pembuatan Media Website Menggunakan WIX & 29 orang & 2 orang \\
\hline 5. & $\begin{array}{l}\text { Pembuatan Media Aplikasi Belajar menggunakan } \\
\text { Appy Pie }\end{array}$ & 26 orang & 5 orang \\
\hline
\end{tabular}

Keterangan:

Tepat waktu: Jumlah mahasiswa yang mengumpulkan tepat waktu pada saat hari presentasi.

Terlambat: Jumlah mahasiswa yang mengumpulkan terlambat karena tidak hadir saat hari presentasi.

\section{Perbandingan Nilai Angket Mahasiswa}

Data angket yang terkumpul kemudian dianalisis untuk menguji hipotesis yang diajukan dengan hasil sebagai berikut.

Tabel 5. Hasil Uji Wilcoxon yang Membandingkan Nilai Self-Regulated Learning Sebelum dan Sesudah Pembelajaran

\begin{tabular}{lll}
\hline & $\begin{array}{l}\text { Angket Akhir - Angket Awal Angket } \\
\text { Eksperimen }\end{array}$ & $\begin{array}{l}\text { Akhir - Angket Awal } \\
\text { Kontrol }\end{array}$ \\
\hline$Z$ & $-.693^{\mathrm{a}}$ & $-2.527^{\mathrm{b}}$ \\
\hline Asymp. Sig. (2-tailed) & .488 & .012 \\
\hline
\end{tabular}
a. Based on positive ranks.
b. Based on negative ranks.
c. Wilcoxon Signed Ranks Test 
Hasil Uji Wilcoxon menunjukkan nilai asymp.sig pada kelas eksperimen lebih besar dari 0,05 sehingga $\mathrm{H}_{0}$ diterima dan $\mathrm{H}_{1}$ ditolak. Artinya tidak terdapat perbedaan nilai angket awal dan angket akhir Self-Regulated Learning Mahasiswa yang menggunakan Edmodo.

Tabel 6. Hasil Uji Mann-Whitney yang Membandingkan Nilai Self-Regulated Learning Antara Kelompok Eksperimen dan Kontrol

\begin{tabular}{ll}
\hline & Nilai SRL Mahasiswa \\
\hline Mann-Whitney U & 310.000 \\
\hline Wilcoxon W & 661.000 \\
\hline Z & -.517 \\
\hline Asymp. Sig. (2-tailed) & .605 \\
\hline a. Grouping Variable: Kelas
\end{tabular}

Berdasarkan hasil uji statistik diketahui bahwa nilai asymp.sig (2-tailed) sebesar 0,605 > 0 ,05. Maka dapat disimpulkan bahwa $H_{0}$ diterima dan $H_{1}$ ditolak. Dengan demikian dapat disimpulkan bahwa tidak terdapat perbedaan nilai Self-Regulated Learning yang signifikan antara kelas eksperimen yaitu mengumpulkan tugas menggunakan Edmodo dengan kelas kontrol yaitu mengumpulkan tugas secara langsung.

\section{Penggunaan Edmodo pada Mata Kuliah Media Pembelajaran Pendidikan Teknologi Agroindustri}

Edmodo diaplikasikan pada Mata Kuliah Media Pembelajaran Pendidikan Teknologi Agroindustri pada mahasiswa semester empat sebagai media pengumpulan tugas secara daring yang juga berfungsi sebagai e-portofolio. Pada penelitian ini penggunaan Edmodo sebagai media pengumpulan tugas dijadikan perlakuan untuk meningkatkan Self-Regulated Learning mahasiswa dengan menekankan pada sub-indikator manajemen waktu. Pintrich, dkk. (1991) mendeskripsikan yang termasuk manajemen waktu adalah penjadwalan, perencanaan, dan pengaturan waktu belajar. Bukan hanya menentukan blok-blok waktu yang akan digunakan untuk belajar, tetapi juga memperhatikan keefektifan penggunaan waktu belajar dan penentuan tujuan yang realistis.

Penggunaan Edmodo dapat digunakan untuk meningkatkan sub-indikator manajemen waktu karena pada Edmodo terdapat fitur Edmodo Planner (perencana) seperti pada Gambar 1. Fitur Edmodo Planner dapat digunakan oleh mahasiswa dan dosen untuk berbagi jadwal baik tugas maupun perkuliahan, oleh karena itu Edmodo dapat menunjang dan memperkuat manajemen waktu karena mahasiswa mendapat perencanaan tugas dari dosen lebih jelas dibandingkan rencana yang diinformasikan secara lisan. Planning atau perencanaan merupakan fase pertama pada proses Self-Regulated Learning. Hal tersebut dijelaskan oleh Pintrich et.al. (2000) yang menjelaskan bahwa fase pertama pada Self-Regulated Learner adalah pemikiran, perencanaan, dan aktivasi. Dimana pada area perilaku Self-Regulated Learner salah satunya melakukan perencanaan waktu.

Tabel 2 menunjukkan jadwal pengumuman dan pengumpulan tugas yang dilaksanakan selama penelitian. Dua tugas pertama diumumkan melalui Edmodo satu hari sebelum waktu pengumpulan karena masih beradaptasi dalam penggunaan Edmodo. Sedangkan tugas selanjutnya diumumkan satu sampai tiga pekan sebelum waktu pengumpulan. Pengumuman tugas dilakukan jauh sebelum tenggat waktu untuk melihat respon mahasiswa terhadap suatu tugas dan manajemen waktu dalam mengerjakan tugas tersebut.

Hasil pada Tabel 3 dapat dilihat bahwa sejumlah mahasiswa dapat mengumpulkan tugas sebelum tenggat waktu yang ditentukan. Mulai dari tugas pertama sampai tugas kelima jumlah mahasiswa yang mengumpulkan tepat waktu berkurang dan berubah menjadi mengumpulkan sebelum tenggat waktu atau lebih awal. Perubahan ini dapat terjadi karena penggunaan Edmodo dalam pengumpulan tugas dapat membantu mahasiswa memantau perkembangan tugasnya. 
Penelitian yang dilakukan oleh Utami (2015) menunjukkan hasil keaktifan siswa yang memanfaatkan e-portofolio menggunakan Edmodo lebih tinggi dibandingkan keaktifan siswa yang memanfaatkan portofolio berbasis kertas.

Jadwal yang terus muncul dan menunjukkan jumlah tugas yang belum terselesaikan pada akun mahasiswa menyebabkan mahasiswa berpikir dan termotivasi mempersiapkan strategi untuk menyelesaikan tugas berikutnya. Hal ini dapat disebut dengan motivasi berkelanjutan. Menurut Paris dan Winograd (1999) Self-Regulated Learning melibatkan keputusan motivasional tentang tujuan suatu kegiatan, kesulitan yang dirasakan, penilaian terhadap tugas, persepsi diri terhadap kemampuan pelajar untuk menyelesaikan tugas dan potensi manfaat keberhasilan atau pertanggungjawaban kegagalan. Kesadaran dan refleksi dapat mengarah pada berbagai tindakan tergantung motivasi orang yang bersangkutan.

Selain itu, terlihatnya informasi tugas seperti terlihat pada Gambar 1 memudahkan mahasiswa melakukan pemantauan terhadap pengerjaan tugasnya. Dalam Self-Regulated Learning proses ini termasuk ke dalam fase kedua yang oleh Zimmerman dan Moylan (2009) disebut performance phase atau fase monitoring menurut Pintrich (2000). Pada fase monitoring ini menurut Pintrich (2000) terjadi proses kesadaran metakognitif dan pemantauan kognisi pada area kognitif, proses kesadaran dan pemantauan motivasi dan pengaruh pada area motivasi, terjadi kesadaran dan pemantauan upaya, penggunaan waktu, dan kebutuhan akan bantuan serta pengamatan diri terhadap perilaku pada area perilaku, dan pada area konteks terdapat proses memantau perubahan tugas dan kondisi konteks.

Meskipun demikian, tidak dapat dihindarkan pula kemungkinan faktor eksternal yang dapat mempengaruhi pengumpulan tugas yang lebih cepat, salah satunya adalah tingkat kesukaran dari tugas yang dikumpulkan. Jika diperhatikan, dari tugas kedua sampai tugas ketiga tingkat kesukaran tugas menurun. Meskipun proses pembuatan media video menggunakan Powtoon hampir sama dengan pembuatan media video tutorial, namun karena pembuatan media pada tugas pertama hingga terakhir menggunakan materi yang sama maka membuat media video tutorial lebih mudah karena dapat menggunakan konten dari Powtoon. Pembuatan media Website menggunakan WIX juga dianggap lebih mudah dari pada membuat video. Sedangkan pada tugas kelima kesukaran tugas meningkat meskipun jumlah mahasiswa yang mengumpulkan tepat waktu menjadi lebih sedikit dan sisanya mengumpulkan tugas pada satu sampai tiga hari sebelum tenggat waktu pengumpulan.

Pada kelas eksperimen terdapat beberapa mahasiswa yang terlambat mengumpulkan melalui Edmodo meskipun telah dibuka permintaan ulang untuk mengumpulkan seperti terlihat pada Tabel 3. Hal ini disebabkan kurangnya kedisiplinan dalam penggunaan Edmodo, mahasiswa yang terlambat mengumpulkan masih diperbolehkan mengumpulkan tugas secara langsung saat hari presentasi tanpa diberikan sanksi. Hal ini dijelaskan oleh Paris dan Winograd (1999) bahwa strategi manajemen guru dilihat setiap hari oleh peserta didik dan jika guru tidak teratur, itu mendorong peserta didik untuk tidak teratur juga. Alasan mahasiswa yang tidak mengumpulkan tugas melalui Edmodo adalah masalah jaringan internet.

Pada kelas kontrol tugas dikumpulkan kepada penanggung jawab kelas dalam satu flash disk dan diserahkan kepada dosen pengampu. Jika terjadi perubahan jadwal perkuliahan maka jadwal pengumpulan tugas pun ikut berubah sesuai berubahnya jadwal kuliah. Pada Tabel 3 dapat dilihat jumlah mahasiswa yang mengumpulkan tugas tepat waktu dan terlambat pada setiap tugas. Mahasiswa yang terlambat mengumpulkan adalah mahasiswa yang tidak hadir saat pertemuan di kelas. Kelebihan dari Edmodo dibandingkan pengumpulan secara konvensional adalah mahasiswa dapat tetap mengumpulkan tugas sesuai tenggat waktu meskipun berhalangan hadir pada pertemuan di kelas. Penggunaan Edmodo juga dapat memberikan catatan keterlambatan dengan jelas yang dapat diketahui oleh dosen dan mahasiswa yang bersangkutan. Hal tersebut bermanfaat untuk proses evaluasi dan refleksi baik bagi mahasiswa maupun dosen.

Selain itu, kelompok eksperimen dosen dapat memberikan umpan balik secara langsung dan terdokumentasikan pada fitur komentar (gambar 2). Sehingga jika terdapat kesalahan pada 
tugas yang dikumpulkan dapat langsung meminta untuk diperbaiki dan dikumpulkan kembali. Jika mahasiswa menunjukkan sikap positif seperti mengumpulkan tugas lebih awal dosen juga dapat langsung memberikan umpan balik seperti memberikan pujian atau mendorong mahasiswa tersebut untuk segera mengumpulkan tugas selanjutnya.

\section{Perbandingan Perubahan Nilai Self-Regulated Learning Mahasiswa}

Meskipun hasil analisis data menunjukkan bahwa tidak terdapat perbedaan nilai angket awal dan angket akhir Self-Regulated Learning Mahasiswa yang menggunakan Edmodo namun seperti pada pembahasan sebelumnya terdapat beberapa mahasiswa yang dapat mengumpulkan tugas lebih awal. Bahkan terdapat mahasiswa yang mengumpulkan tugas 14 hari sebelum tenggat waktunya. Artinya penggunaan Edmodo memfasilitasi pengumpulan bagi mahasiswa yang dapat menyelesaikan tugas lebih awal dari tenggat waktu yang ditentukan.

Faktor yang dapat menyebabkan penggunaan Edmodo tidak memberikan perbedaan nilai angket awal dan akhir adalah kurang dimanfaatkannya fitur-fitur pada Edmodo. Salah satu fitur yang tidak dimanfaatkan adalah fitur penilaian terhadap tugas yang dikumpulkan. Mahasiswa tidak dapat langsung melihat nilai dari tugas yang dikumpulkannya sehingga proses refleksi masih kurang. Sementara refleksi merupakan salah satu proses penting yang dapat menguatkan SelfRegulated Learning mahasiswa. Menurut Paris dan Winograd (1999) Self-Regulated Learning dapat dipromosikan melalui pencatatan tujuan yang tercapai, nilai yang diterima, dan kemajuan yang dibuat dalam manajemen perilaku dan pembelajaran. Guru yang menggunakan portofolio atau pencatatan jurnal akan memahami bagaimana penilaian diri secara berkala dapat menyebabkan perasaan bangga atau upaya baru.

Meskipun pada Mata Kuliah Media Pembelajaran terdapat sesi presentasi hasil kerja dan penilaian dari teman sebaya, namun hasil penilaiannya tidak diterima langsung oleh mahasiswa yang bersangkutan. Pemberian evaluasi secara berkala baik berupa skor nilai maupun bentuk umpan balik lainnya dapat menjadi perhatian bukan hanya untuk Mata Kuliah Media Pembelajaran saja melainkan untuk mata kuliah lainnya. Karena penilaian formatif berguna bukan hanya untuk memberikan motivasi berupa perasaan bangga ataupun memunculkan upaya dari angka yang diterima. Penilaian secara berkala juga memberikan informasi kepada peserta didik tentang pemahamannya terhadap suatu materi. Pada bagian mana dirinya melakukan kesalahan dalam memahami suatu konsep pada mata kuliahnya dan bagian mana dirinya melakukan pengembangan ide yang sangat baik.

Proses refleksi termasuk ke dalam fase ketiga menurut Zimmerman (2009) dalam SelfRegulated Learning yaitu fase Self-Reflection. Fase refleksi melibatkan proses yang mengikuti upaya pembelajaran tetapi juga memengaruhi reaksi pelajar terhadap pengalaman belajarnya. Refleksi diri ini, pada gilirannya, mempengaruhi pemikiran tentang upaya pembelajaran selanjutnya, yang melengkapi siklus Self-Regulated Learning. Dalam keseluruhan proses SelfRegulated Learning belajar tidak berhenti dan terfokus pada pengumpulan suatu informasi atau keterampilan oleh seorang pelajar. Agar dapat berkembang, seorang pelajar harus melakukan evaluasi dan refleksi atas kinerjanya. Tinjauan literatur yang dilakukan oleh Yatibas, A.E. dan Yatibas, C.G. (2015) menunjukkan bahwa penilaian berbasis e-portofolio dapat digunakan untuk mengembangkan Self-Regulated Learning siswa dalam pengajaran bahasa Inggris karena fokus utamanya adalah pada siswa. Tujuan dari bentuk penilaian e-portofolio adalah untuk memungkinkan siswa untuk mempersonalisasikan pembelajaran mereka dengan mendukung dan mendorong partisipasi aktif, mengambil tanggung jawab dari pembelajaran sendiri, pengamatan dan refleksi pembelajaran oleh siswa. Ini menunjukkan bahwa Self-Regulated Learning dan eportofolio dapat terhubung satu sama lain, dan penilaian berbasis e-portofolio dapat mempromosikan Self-Regulated Learning.

Hasil angket awal dan angket akhir juga tidak berbeda akibat perlakuan yang tidak sesuai dengan keadaan dan kebutuhan mahasiswa. Nilai paling rendah diperoleh pada sub-indikator mengorganisir informasi, pengaturan mandiri metakognitif, dan peer learning (pembelajaran e-ISSN: 2541-4593 http://ejournal.upi.edu/index.php/edufortech/index 
dengan teman sebaya). Sementara perlakuan yang dilakukan lebih menekankan pada strategi manajemen waktu dan lingkungan sehingga tidak sesuai dengan kebutuhan responden. Oleh karena itu, menjadi catatan juga bagi pendidik yang berorientasi untuk meningkatkan katerampilan belajar peserta didiknya untuk mampu mendiagnosis keadaan peserta didik dengan benar.

Diagnosis yang benar akan memberikan pilihan perlakuan yang tepat bagi tenaga pendidik untuk membantu menyelesaikan permasalahan yang dialami peserta didiknya. Seorang mahasiswa dengan mahasiswa lain dapat memiliki nilai Self-Regulated Learning yang sama namun bisa terjadi perbedaan nilai pada setiap aspeknya. Mahasiswa dengan nilai Self-Regulated Learning yang termasuk pada kategori tinggi pun masih bisa memiliki sub-indikator dengan nilai yang sangat rendah. Diagnosis ini harus dilakukan pada setiap mahasiswa dan tidak digeneralisasikan pada sebuah kelompok mahasiswa akan tetapi memperhatikan keadaan setiap individu. Jika memungkinkan dosen dapat memperhatikan perkembangan seluruh mahasiswa namun jika sulit maka dosen dapat berfokus pada mahasiswa dengan keadaan yang sangat membutuhkan bimbingan dan bantuan dalam proses belajarnya.

Meskipun portofolio dapat menjadi contoh terbaik dari alat penilaian yang mempromosikan Self-Regulated Learning, penggunaannya perlu dipersiapkan secara terkonsep. Hal ini mendapat perhatian dari Paris dan Winograd (1999) yang menyarankan program studi pendidikan guru perlu menggunakan portofolio lebih sering dan dengan cara yang lebih dikonsep secara konseptual sehingga calon guru memahami cara memperkenalkan dan melatih refleksi peserta didik, bukan hanya sebagai koleksi.

\section{KESIMPULAN}

1. Penggunaan Edmodo pada Mata Kuliah Media Pembelajaran Pendidikan Teknologi Agroindustri dapat memfasilitasi mahasiswa untuk mengumpulkan tugas lebih awal dan memonitor perkembangan penyelesaian tugas menggunakan fitur Edmodo Planner. Pembelajaran menggunakan Edmodo tidak meningkatkan seluruh sub-indikator dalam SelfRegulated Learning.

2. Berdasarkan hasil analisis data dapat disimpulkan tidak terdapat perbedaan nilai Self-Regulated Learning pada angket awal dan angket akhir mahasiswa yang menggunakan Edmodo. Nilai Self-Regulated Learning setelah pembelajaran atau nilai angket akhir kelompok kontrol dan kelompok eksperimen juga tidak berbeda signifikan.

\section{DAFTAR PUSTAKA}

Creswell, J. W. (2009). Research Design: Qualitative, Quantitative, and Mixed Methods Approaches. USA: University of Nebraska-Lincoln.

Paris, S.G. \& Winograd, P. (1999). The Role of Self-Regulated Learning in Contextual Teaching: Principles and Practices for Teacher Preparation. [Online]. Diakses dari http://www.ciera.org/library/archive/2001-04/0104parwin.htm

Pintrich, P.R., Wolters, C.A. \& Baxter, G.P. (2000). 2. Assessing Metacognition and Self-Regulated Learning. Issues in the Measurement of Metacognition, 3.

Pintrich, P.R., et.al. (1991). A Manual for the Use of the Motivated Strategies for Learning Questionnaire (MSLQ). National Center for Research to Improve Postsecondary Teaching and Learning, Ann Arbor, MI.

Safa'ati, E., Halim, M.I. \& Iliyati, Z. (2017). "Peran Regulasi Diri dan Konformitas Teman Sebaya dengan Prokrastinasi Akademik Mahasiswa Universitas Muria Kudus". Dalam S. El Hafiz (Penyunting), Prosiding Konferensi Nasional Peneliti Muda Psikologi Indonesia 2017, 2(1), 75-84.

Sumarmo, U. (2004). Kemandirian Belajar: Apa, Mengapa, dan Bagaimana Dikembangkan pada Peserta Didik. Fakultas Pendidikan Matematika dan IImu Pengetahuan Alam, Universitas Pendidikan Indonesia 
Utami, N.R. (2015). Efektivitas E-Portofolio Menggunakan Edmodo Terhadap Keaktifan dan Hasil Belajar Siswa pada Mata Pelajaran Fotografi Kelas X Jurusan Multimedia di SMK Negeri 2 Sewon. (Skripsi). Program Studi Teknik Informatika, Fakultas Teknik, Universitas Negeri Yogyakarta.

Yastibas, A.E. \& Yastibas, G.C. (2015). The Use of E-Portfolio-Based Assessment to Develop Students' Self-Regulated Learning in English Language Teaching. Procedia Social and Behavioral Science, 176, 3-13.

Zimmerman, B.J. (2002). Becoming a Self Regulated Learner: An Overview. Theory Into Practice, 41(2), 64-70. doi: 10.1207/s15430421tip4102_2.

Zimmerman, B.J. \& Moylan, A. R. (2009). Self-Regulation: Where Metacognition and Motivation Intersect. Dalam D.J. Hacker., J. Dunlosky., \& A.C. Graesser (Penyunting), Handbook of Metacognition in Education, 299-315. New York: Routledge. 